\title{
KEJADIAN DEMAM NEUTROPENIA PADA PASIEN KANKER PAYUDARA YANG MENDAPAT KEMOTERAPI
}

\author{
Rulli Firmansyah ${ }^{1}$, Daan Khambri ${ }^{1}$, Edison $^{2}$, Zelly Dia Rofinda ${ }^{3}$
}

\begin{abstract}
Abstrak
Kemoterapi memiliki peranan penting dalam penatalaksanaan kanker payudara. Obat ini bekerja membunuh sel-sel kanker, namun dapat juga menghancurkan sel-sel sehat termasuk sel darah sehingga dapat menyebabkan neutropenia. Penelitian ini bertujuan untuk mengetahui kejadian demam neutropenia pada pasien kanker payudara yang mendapat kemoterapi. Jenis penelitian ini adalah obsevasional dengan desain cross sectional study. Jumlah sampel sebanyak 98 orang penderita kanker payudara yang menjalani kemoterapi di RSUP Dr. M Djamil Padang. Pemeriksaan yang dilakukan adalah differential count dan suhu tubuh oral, kemudian dilakukan analisis statistik dengan uji non parametrik. Kejadian demam neutropenia ditemukan pada 10 pasien $(10,2 \%)$, dimana didapatkan hubungan yang bermakna antara regimen kemoterapi dengan kejadian demam neutropenia $(p=0,028)$, dan tidak terdapat hubungan yang bermakna antara kejadian demam neutropenia dengan umur pasien $(p=0,683)$ serta setting kemoterapi $(p=0,631)$. Hubungan antara kejadian demam neutropenia dengan siklus kemoterapi tidak dapat dianalisis secara statistik. Penelitian ini dapat disimpulkan bahwa regimen kemoterapi non FAC meningkatkan resiko kejadian demam neutropenia pada pasien kanker payudara yang dikemoterapi.
\end{abstract}

Kata kunci: demam neutropenia, kemoterapi, kanker payudara

\begin{abstract}
Chemotherapy has an important role in breast cancer management. Chemotherapy works by killing cancer cells in the body. However, healthy cells including blood cells are also destroyed leading to a condition called neutropenia. This study aimed to determine the incidence of neutropenia febrile in patients with breast cancer who received chemotherapy in the chemotherapy unit of Dr. M. Djamil Padang Hospital. This study was a cross-sectional study of 98 samples. Leucosite differential count and oral body temperature were examined and were analyzed with non parametric test. Neutropenia febriles were found on 10 out of 98 patients (10.2\%). There was a significant association found between chemotherapy regimen and the incidence of neutropenia febrile $(p=0.028)$, however, there were no significant association between the incidence of neutropenia febrile with patient's age $(p=0.683)$ and the setting of chemotherapy $(p=0.631)$. While the correlation between the incidence of neutropenia febrile and chemotherapy cycle can not be statistically analyzed. It is concluded that chemotherapy causes incidence of neutropenia febrile at $10.2 \%$ patient. Non FAC chemotherapy regimens increases the risk of neutropenia febrile in patients with breast cancer patient receiving chemotherapy.
\end{abstract}

Keywords: neutropenia febrile, chemotherapy, breast cancer

Afiliasi Penulis : 1. Bagian IImu Bedah Fakultas Kedokteran UNAND RS DR M. Djamil Padang. 2. Bagian IImu Kesehatan Masyarakat FK UNAND. 3. Bagian Patologi Klinik FK UNAND RS Dr. M. Djamil Padang. Korespondensi: Rulli Firmansyah, Email: firmansyahrulli@gmail.com, HP: 08126730942. 


\section{PENDAHULUAN}

Kanker payudara merupakan penyebab kematian utama pada wanita. Kejadian kanker payudara pada wanita tahun 2012 sebanyak 1,7 juta dan hanya $6,3 \%$ wanita yang masih bertahan hidup setelah didiagnosis menderita kanker payudara 5 tahun sebelumnya. Sejak estimasi pada tahun 2008 kejadian kanker payudara meningkat lebih dari 20\%, sementara kematian yang disebabkan kanker payudara meningkat sebesar $14 \%$. $^{1,2}$

Angka kejadian kanker payudara di Indonesia tahun 2008 mencapai 36,2 kasus per 100.000 penduduk dengan jumlah 39.831 kasus baru. ${ }^{1}$ Berdasar kan Sistem Informasi Rumah Sakit (SIRS) pada tahun 2010, kanker payudara merupakan jenis kanker tertinggi pada pasien rawat inap maupun rawat jalan di seluruh rumah sakit di Indonesia dengan proporsi sebesar $28,7 \%{ }^{3}$

Terapi kanker payudara dapat digolongkan menjadi pembedahan, kemoterapi, radioterapi, dan terapi hormonal. Kemoterapi (adjuvan/ neoadjuvan/ primer) memiliki peranan penting terhadap penatalaksanaan kanker payudara. Efek samping kemoterapi timbul karena obat-obat kemoterapi tidak hanya menghancurkan sel-sel kanker tetapi juga menyerang sel-sel sehat, salah satunya gangguan pembentukan neutrofil. Hal ini terjadi akibat efek mielosupresif kemoterapi. ${ }^{4,5}$

Protokol kemoterapi yang banyak digunakan di bangsal Bedah RSUP Dr. M. Djamil Padang adalah protokol kemoterapi regimen 5Fluorouracil, Doxorubicin (adriamycin), Cyclophosphamide, yang disingkat FAC. ${ }^{6}$

Neutropenia adalah kelainan pada darah yang diidentifikasi dengan jumlah sel neutrofil yang rendah. Sel-sel neutrofil adalah bagian dari sel darah putih atau leukosit (sekitar 50 - 70\% dari total sel darah putih) yang berada dalam sirkulasi. Sel neutrofil ini berperan sebagai penangkal infeksi. Fungsi sel ini adalah membunuh bakteri yang berada dalam darah, oleh karena itu, pasien yang mengalami neutropenia menjadi lebih rentan terhadap infeksi bakteri dan dapat secara langsung mengancam kehidupan mereka bila tidak segera ditangani.

Neutropenia dapat berlangsung akut atau kronis, dimana tergantung dari lama terjadinya penyakit. Pasien dinyatakan menderita neutropenia kronis bilamana ia mengalaminya selama lebih dari 3 bulan. Penyakit ini terkadang disebut juga dengan istilah leukopenia. Tetapi neutropenia lebih tepat dikatakan sebagai bagian dari leukopenia. ${ }^{7}$

Kemoterapi yang dijalani seorang pasien bekerja dengan cara membunuh sel-sel kanker yang ada di tubuh. Sayangnya terapi ini umumnya tidak bisa mengenali perbedaan antara sel kanker dengan sel sehat, akibatnya kemoterapi menghancurkan sel-sel sehat, baik pada sel rambut, kulit, tulang, darah dan lainnya. Salah satu sel darah yang dapat dipengaruhi adalah sel darah putih. Oleh 
karena itu neutropenia menjadi salah satu efek samping yang kerap terjadi ${ }^{7}$.

Demam neutropenia merupakan kejadian yang sering dialami oleh pasien dengan keganasan dan dapat disebabkan oleh proses lain seperti infeksi maupun non infeksi (penyakit primer), reaksi transfusi, dan efek samping kemoterapi. Demam pada neutropenia merupakan kedaruratan onkologi yang membutuhkan penanganan cepat dengan pemberian antibiotik yang tepat. $^{7}$

Kemoterapi sebagai salah satu penyebab neutropenia menimbulkan demam pada 25-40\% kasus, karena kejadian tersebut dapat mengakibatkan penundaan pemberian kemoterapi pada pasien tersebut ${ }^{8}$.

Berdasarkan latar belakang di atas dapat diasumsikan bahwa kemoterapi yang dilakukan pada pasien kanker dapat menimbulkan neutropenia yang akan berakibat terjadinya deman neutropenia. Penelitian ini bertujuan untuk membuktikan kejadian demam neutropenia pada pasien kanker payudara yang mendapat kemoterapi.

\section{METODE}

Jenis penelitian ini adalah observasional dengan desain cross sectional study. Penelitian dilakukan pada 98 orang penderita kanker payudara yang mendapatkan kemoterapi di Unit Kemoterapi, poli bedah RSUP Dr. M. Djamil Padang.

Kriteria inklusi yaitu semua penderita kanker payudara pada semua usia dan semua stadium yang menjalani kemoterapi. Kriteria Ekslusi yaitu penderita kanker payudara yang di kemoterapi pada siklus yang pertama, penderita kanker payudara yang di kemoterapi dengan seting kemoterapi primer, penderita kanker payudara yang di kemoterapi dengan demam tanpa neutropenia, penderita kanker payudara yang di kemoterapi yang menolak ikut dalam penelitian.

Variabel bebas pada penelitian ini adalah regimen kemoterapi, siklus kemoterapi, seting kemoterapi, dan umur. Variabel tergantung adalah demam neutropenia. Pemeriksaan yang dilakukan adalah differrential count leukosit dan suhu tubuh oral. Data diolah dengan menggunakan program computer. Analisa data dengan mengunakan rumus Fishers Exact Test dengan derajat kepercayaan $95 \%$.

\section{HASIL DAN PEMBAHASAN}

Hasil penelitian ini didapatkan distribusi frekuensi penderita kanker payudara yang mendapatkan kemoterapi berdasarkan umur, siklus dan seting kemoterapi, regimen serta jumlah dari neutrofil (tabel.1).

Tabel 1. dapat dilihat bahwa sebagian besar penderita kanker payudara berumur $\geq 40$ tahun yaitu sebanyak 80 orang (81.6\%). Penderita sebagian besar melakukan kemoterapi di siklus ke II sebanyak 33 orang (33.7\%). Penderita yang melakukan kemoterapi pada setingan adjuvant sebanyak 84 orang (85,7\%). Perbandingan yang menggunakan regimen $F A C$ dan non FAC adalah 65 orang (63,3\%) banding 
33 orang (33,7\%). Penderita yang mengalami neutropeni sebanyak 20 orang $(20.4 \%)$ dari 98 penderita yang diteliti.

\section{Tabel 1. Distribusi Frekuensi} Penderita Kanker Payudara yang Dikemoterapi

\begin{tabular}{ll}
\hline Distribusi Penderita & $\mathbf{f}(\%)$ \\
\hline
\end{tabular}

\begin{tabular}{|c|c|}
\hline Jmur ( $T$ & \\
\hline$<40$ & $18(18.4)$ \\
\hline$\geq 40$ & $80(81.6)$ \\
\hline
\end{tabular}

Siklus Kemoterapi

$\begin{array}{ll}\text { II } & 33(33.7) \\ \text { III } & 30(30.6) \\ \text { IV } & 12(12.2) \\ \text { V } & 13(13.3) \\ \text { VI } & 10(10.2)\end{array}$

Setting Kemoterapi

Adjuvant

Neo adjuvant

Regimen

FAC $65(66,3)$

NON FAC $33(33,7)$

Jumlah Neutrofil

Neutropeni $20(20,4)$

Tidak Neutropeni $78(79,6)$ payudara yang menjalani kemoterapi berdasarkan umur dapat dilihat pada tabel 2.

Tabel 2. Kejadian Demam Netropenia Pasien Berdasarkan Umur

\begin{tabular}{ccrc}
\hline \multirow{2}{*}{ Umur } & \multicolumn{2}{c}{ Demam Neutropenia } & \\
\cline { 2 - 3 } & Ya (\%) & Tidak (\%) & P \\
\hline 40 & $1(5,6)$ & $17(94.4)$ & 0.683 \\
$\geq 40$ & $9(11,3)$ & $71(88.7)$ & \\
\hline
\end{tabular}

Tabel 2 dapat dilihat bahwa persentase kejadian demam neutropenia berdasarkan umur, tertinggi ditemukan pada umur $\geq 40$ tahun yaitu sebesar $11.3 \%$, dan umur < 40 sebesar $5.6 \%$. Secara statistik hubungan ini tidak signifikan ( $p>0,05)$, yang berarti tidak ada hubungan antara kejadian demam neutropenia dengan umur. Sedangkan hubungan kejadian demam neutropenia pada penderita kanker payudara yang mendapatkan kemoterapi dengan regimen kemoterapi yang dipakai dapat dilihat pada tabel 3 .

Tabel 3. Kejadian Demam Neutropenia Pasien Berdasarkan Regimen

$\begin{array}{llll}\text { FAC } \quad 3(4,6) \quad 62(95.4) & 0.028\end{array}$

Hubungan kejadian demam Non FAC $7(21,2) \quad 26(78.8)$ 
Tabel 3, dapat dilihat bahwa persentase kejadian demam neutropenia terbanyak berdasarkan regimen kemoterapi yang digunakan yaitu pada regimen non FAC sebesar $21.2 \%$, sedangkan regimen FAC $4.6 \%$. Hubungan ini secara statitik didapatkan signifikan $(p<0,05)$, dimana terdapat hubungan bermakna kejadian demam neutropenia dengan regimen kemoterapi.

Penelitian ini juga melihat hubungan antara kejadian demam neutropeni dengan siklus kemoterapi seperti yang diperlihatkan oleh tabel 4 .

Tabel 4. Kejadian Demam Neutropenia Berdasarkan Siklus

\begin{tabular}{ccc}
\hline \multirow{2}{*}{ Siklus } & \multicolumn{2}{l}{ Demam Neutropenia } \\
\cline { 2 - 3 } & Ya (\%) & Tidak (\%) \\
\hline II & $1(3.03)$ & $32(95.4)$ \\
III & $6(20)$ & $24(80)$ \\
IV & $2(16.7)$ & $10(83.3)$ \\
V & $1(7.7)$ & $12(92.3)$ \\
VI & $0(0)$ & $10(100)$ \\
\hline
\end{tabular}

Berdasarkan tabel 4, dapat dilihat persentase kejadian demam neutropeni berdasarkan siklus kemoterapi yang terbanyak adalah pada siklus kemoterapi ketiga yaitu sebanyak 6 kasus (20\%) dan paling sedikit pada siklus II sebanyak 1 kasus (3.03\%).

Tabel 5 memperlihatkan hubungan kejadian demam neutropenia berdasarkan seting kemoterapi.
Tabel 5. Kejadian Demam Neutropenia Berdasarkan Seting Kemoterapi

\begin{tabular}{llll}
\hline \multirow{2}{*}{$\begin{array}{l}\text { Seting } \\
\text { Kemoterapi }\end{array}$} & \multicolumn{2}{c}{ Demam Neutropenia } & P \\
\cline { 2 - 3 } & Ya (\%) & Tidak (\%) & \\
\hline Adjuvan & $8(9,5)$ & $76(90,5)$ & 0.632 \\
Neoadjuvan & $2(14,3)$ & $12(85,7)$ & \\
\hline
\end{tabular}

Tabel 5, dapat dilihat bahwa persentase kejadian demam neutropenia berdasarkan seting kemoterapi tertinggi didapatkan pada seting kemoterapi neoadjuvant yaitu sebesar $14.3 \%$ dan adjuvan sebesar $9.5 \%$. Secara statistik hubungan ini tidak signifikan dimana nilai p yang didapat besar dari 0,05. Hal ini dapat ditarik kesimpulan bahwa tidak terdapat hubungan antara kejadian demam neutropeni dengan seting kemoterapi.

Penelitian ini didapatkan jumlah sampel yang memenuhi kriteria inklusi adalah sebanyak 98 orang pasien kanker payudara yang mendapat kemoterapi di Unit Kemoterapi RSUP Dr. M. Djamil Padang. didapatkan bahwa sebagian besar penderita berumur $\geq 40$ tahun yaitu 80 penderita (81.6\%). Hasil ini sesuai dengan yang didapat di Indonesia bahwa frekuensi kanker payudara yang tertinggi di temukan pada wanita usia di atas 40 tahun $^{3}$.

Berdasarkan regimen kemoterapi didapatkan penderita paling banyak melakukan kemoterapi dengan regimen FAC sebanyak 65 (66.3\%). Hasil ini sesuai dengan yang didapatkan oleh 
Hafni Marsil (2012). Pasien yang mengalami neutropenia didapatkan sebanyak 20 orang dan 10 pasien $(10,2 \%)$ pasien mengalami demam neutropenia. Hal ini sesuai literatur, dimana kemoterapi sebagai salah satu penyebab neutropenia yang dapat menimbulkan demam pada $25-40 \%$ kasus $^{8}$. Kejadian demam neutropenia menurut WHO dilaporkan sekitar 10-57\% kasus $^{3}$.

Kejadian demam neutropenia pada pasien kanker payudara yang mendapat kemoterapi pada penelitian ini berdasarkan regimen kemoterapi, didapatkan kejadian demam neutropenia 3 kasus pada regimen FAC, sedangkan pada regimen Non FAC sebanyak 7 kasus. Hasil uji statistik dengan derajat kepercayaan 95\% menunjukkan bahwa terdapatnya hubungan yang bermakna antara regimen kemoterapi dengan kejadian demam neutropenia pada pasien kanker payudara dengan nilai $p$ lebih kecil dari $0.05(\mathrm{p}=0.028)$.

Simposium Hematologi Onkologi Medik Penyakit Dalam Indonesia (HOMPEDIN) 2012 dilaporkan bahwa pada kanker payudara, regimen non FAC memperbesar risiko terjadinya demam neutropenia sebesar $23,4-34 \%$. Efek samping yang predominan pada pemberian Paclitaxel adalah efek samping hematologi yaitu neutropenia atau leukopenia dan dapat juga terjadi neuropati perifer ${ }^{9}$. Penambahaan Docetaxel meningkatkan efek samping 3-4 derajat dibandingkan tanpa Docetaxel, yaitu berupa demam neutropenia karena tingginya efek samping mielosupresi ${ }^{10}$.
Kemoterapi Non FAC (Paclitaxel, Docetaxel) meningkatkan risiko demam neutropenia $>20 \%{ }^{11}$.

Kejadian demam neutropeni pada pasien kanker payudara yang di kemoterapi berdasarkan umur didapat kan 9 kasus pada umur $\geq 40$ tahun dan pada umur $<40$ tahun 1 kasus. Hal ini sesuai dengan National Comprehensive Cancer Network Guideline bahwa umur lebih dari 70 tahun meningkatkan risiko demam neutropenia ${ }^{12}$. Uji statistik menunjukkan bahwa tidak ada hubungan yang bermakna antara umur dengan kejadian demam neutropenia pada pasien kanker payudara yang mendapat kemoterapi di Unit Kemoterapi RSUP Dr. M. Djamil Padang.

Kejadian demam neutropeni pada pasien kanker payudara yang di kemoterapi berdasarkan seting kemoterapi, dimana kasus terbanyak terjadinya demam neutropenia yaitu pada seting kemoterapi adjuvant sebanyak 8 kasus, sedangkan seting kemoterapi neoadjuvan hanya 2 kasus. Penelitian ini menemukan bahwa tidak ada hubungan yang bermakna antara seting kemoterapi dengan kejadian demam neutropenia pada pasien kanker payudara.

Kejadian demam neutropeni pada pasien kanker payudara yang di kemoterapi berdasarkan siklus kemoterapi didapatkan kasus kejadian demam neutropenia terbanyak pada siklus II sebanyak 6 kasus. Namun pada penelitian ini tidak bisa dilihat hubungan kejadian deman neutropeni dengan siklus kemoterapi. 


\section{SIMPULAN}

Karakteristik pasien kanker payudara yang di kemoterapi di Unit Kemoterapi RSUP Dr. M. Djamil Padang ditemukan pada umumnya usia $\geq 40$ tahun (81.6\%). Penderita paling sering melakukan kemoterapi pada siklus ke II (33.7\%). Seting kemoterapi terbanyak adalah adjuvant (85.7\%). Regimen kemoterapi yang digunakan terbanyak adalah FAC (66.3\%). Seperlima pasien menjalani kemoterapi mengalami neutropenia (20.4\%). Kejadian demam neutropenia terjadi pada lebih kurang 10 persen kasus.

Penelitian ini ditemukan bahwa terdapat hubungan antara kejadian deman neutropeni dengan regimen kemoterapi pada penderita kanker payudara di Unit Kemoterapi RSUP Dr. M. Djamil Padang, namun tidak terdapat hubungan antara kejadian deman neutropeni dengan umur dan seting kemoterapi. Kejadian demam neutropenia dengan siklus kemoterapi tidak dapat dianalisa secara statistik. Penelitian ini dapat disimpulkan bahwa regimen kemoterapi non FAC meningkatkan resiko kejadian demam neutronpenia pada pasien kanker payudara yang dikemoterapi.

\section{DAFTAR PUSTAKA}

1. Ferlay J, Shin HR, Bray F,Maters C,Parkin DM, 2010. GLOBOCAN 2008 V1.2. Cancer incidence and mortality worldwide: IARC cancer base No. 10 Lyon. France: International Agency for Research on Cancer.[cites; 201325 October]. Available from: http://globocan.iarc.fr.
2. Bray F, Ren JS, Masuyer E, Ferlay J. Global estimates of cancer prevalence for 27 sites in the adult population in 2008. Int J Cancer 2013;132(5):113345.

3. Kementrian Kesehatan Republik Indonesia. Pusat Komunikasi Publik. Diakses dari: http://www. depkes. go.id/index.php/genta/press-release/ 1060.

4. Jong, W.D. Payudara. Dalam. Buku Ajar IImu Bedah. Editor; R. Sjamsuhudijat. Ed 2. EGC. Jakarta 2005:387-402.

5. Noorwati, S. Kemoterapi, Manfaat dan Efek Samping. Dharmais Cancer Hospital. Jakarta 2007.

6. Marsil H. Pengamatan Respon Kemoterapi Pada Penderita Kanker Payudara Yang Dikemoterapi Di Bangsal Bedah RSUP. Dr. M. Djamil Padang Periode Januari 2010-2012. 2012:18-9.

7. De Vita Jr VT. Principles And Practise of Oncology. $5^{\text {th }}$ ed. Lippincot Williams and Wilkins, 2008:1595-1634.

8. Nathan DG, Oski AF. Phagocyte sistem. Dalam: Nathan DG, Oski FA, penyunting. Hematology of Infancy and Childhood. Ed 15. Philadelphia: Lippincott Williams and Walkins; 2001:1239-45.

9. Spencer CM, Faulds D. Paclitaxel : A review of its pharmacodinamic pharmacokinetic properties and the traupeutic potential in the treatment of cancer drugs. 1994. 48(5):794-847.

10. Swain.SM. Chemoterapi: Update and new persfective. Oncolog. 2010. 15(suppl 5) 8-17. 
11. Onco Emergencies- Febrile Neutropenia. Available from: http// www.gics.com.au.

12. Crawford J, Dale DC, Lyman GH. Chemotherapy-induced neutropenia risks, consequences and new direction for its management. American Cancer Society 2003:228-37. Available from: http//www.qu.edu/ pharmacy 